\title{
The Level Of Parents Anxiety On Physical Education Activity At Lintang City Elementry School
}

\author{
Andi Nova), Andrew Rinaldi Sinulingga ${ }^{2)}$, Andri Syahputra ${ }^{3)}$ \\ ${ }^{1,2,3}$ Program Studi Pendidikan Olahraga \\ Fakultas Keguruan dan Ilmu Pendidikan \\ Universitas Samudra, Kota Langsa Aceh Indonesia \\ Email: ${ }^{1}$ andinova@unsam.ac.id, ${ }^{2}$ andrew.rinaldi@lecturer.unri.ac.id, \\ ${ }^{3}$ syahputraandri1995@gmail.com
}

\begin{abstract}
The purpose of this study to determine the level of parent's anxiety on physical education lesson at Lintang City Elementary School. This research method uses a survey and collect the data by using a questionnaire. The scores obtained from questionnaires is analyzed by using quantitative descriptive analysis that converted in the form of percentages. The population the study is all parents of students and the sample is grade I, II, which they are 58 parents by using purposive sampling. The level of anxiety based on physiological factors on restless indicators during the physical education lesson is $74.3 \%$. The level of anxiety based on psychological factors on indicators of worrying about something during physical education lesson is $71.3 \%$, on the indicators of feeling safe and joy is $60.3 \%$, and on the indicators of fear at $74.5 \%$. The results of the study and discussion can be concluded that the level of parental anxiety on Physical Education was classified as high at 70.1\%. in this study, the factor of parents anxiety caused by student activity, especially grade I and II as we know, during practice in this lesson so easy to get injury when the students careless.
\end{abstract}

Keywords: Anxiety of Parents, Physical Education.

\section{Tingkat Kecemasan Orangtua Siswa Sd Negeri Kota Lintang Terhadap Pelajaran Pendidikan Jasmani}

\begin{abstract}
ABSTRAK
Tujuan penelitian mengetahui tingkat kecemasan orangtua terhadap pendidikan jasmani pada siswa SD Negeri Kota Lintang. Metode penelitian ini menggunakan survei dengan teknik pengambilan data menggunakan angket, skor yang diperoleh dari angket kemudian dianalisis menggunakan analisis diskriptif kuantitatif yang dituangkan dalam bentuk persentase. Populasi dalam penelitian ini seluruh orangtua siswa dan sampel adalah siswa kelas I dan kelas II yang berjumlah 58 orang dengan menggunakan purposive sampling. Tingkat kecemasan berdasarkan faktor fisiologis pada indikator gelisah saat dilakukan pelajaran pendidikan jasmani sebesar 74,3\%. Tingkat kecemasan berdasarkan faktor psikologis pada indikator khawatir tentang sesuatu saat dilakukan pelajaran pendidikan jasmani sebesar 71,3\%, pada indikator perasaan aman dan senang sebesar $60,3 \%$, dan pada indikator ketakutan sebesar 74,5\%. Hasil penelitian serta pembahasan dapat disimpulkan bahwa tingkat kecemasan orangtua terhadap pelajaran pendidikan jasmani tergolong tinggi yakni sebesar 70,1\%. Dalam penelitian ini faktor kecemasan orangtua ditimbulkan oleh aktivitas peserta didik pada kelas I dan II pada saat pembelajaran penjas karena dianggap rentang dengan cidera pada saat aktivitas pendidikan jasmani.
\end{abstract}

Kata Kunci: Kecemasan Orangtua, Pendidikan Jasmani

Info Artikel

Dikirim

Diterima

Dipublikasikan
: 6 April 2020

: 1 Mei 2020

: 11 Mei 2020
(C) 2020 IKIP BUDI UTOMO MALANG

P-ISSN 2613-9421

E-ISSN 2654-8003

\ Alamat korespondensi: andinova@unsam.ac.id

Universitas Samudra, J1, Meurandeh, Langsa Lama, Kota Langsa, Aceh 24354, Indonesia 


\section{PENDAHULUAN}

Pembelajaran merupakan suatu proses menciptakan kondisi untuk memungkinkan siswa dapat belajar. Sehingga disusun dalam bentuk kurikulum yang disesuaikan dengan kebutuhan murid dalam melaksanakan kegiatan belajar mengajar (Depdiknas, 2006) salah satunya pendidikan jasmani. Pendidikan jasmani merupakan bagian integral pendidikan, mempunyai tantangan yang semakin besar untuk mengimplementasikan apa yang terkandung dalam kurikulum dalam rangka pembangunan generasi yang lebih baik (widiyatmoko dan Hudah, 2017). Seperti yang sudah tertulis dalam kurikulum berbasis kompetensi mata pelajaran pendidikan jasmani merupakan fundamental pendidikan secara keseluruhan, bertujuan untuk mengembangkan aspek kesehatan, kebugaran, keterampilan motorik, berfikir kritis, stabilitas emosional, keterampilan sosial, penalaran dan tindakan moral melalui kegiatan aktivitas pendidikan jasmani. Beranjak dari pernyataan tersebut dapat diartikan bahwa pendidikan jasmani sangat penting khususnya pada anak dalam masa proses belajar gerak yang ingin mencoba berbagai hal.

Pelaksanaan pendidikan jasmani jenjang sekolah dasar kebenaran gerak sangat fundamental, banyak hal yang harus diperhatikan untuk membentuk karakter, gerak dasar, interaksi sosial yang tujuanya membentuk keterampilan dalam berfikir, memecahkan masalah, emosional dan sosial. Pendidikan jasmani merupakan cara membina anak agar menguasai cabang-cabang olahraga tertentu (Setyawan, 2018). Ini merupakan tindakan otomatisasi pembelajaran secara saintifik dimana siswa akan menyukai pembelajaran pendidikan jasmani yang akan menjadi keahlian anak dalam kecabangan olahraga.

Masalah ini tidak muda dilakukan oleh guru pendidikan jasmani di sekolah, sebab banyak aspek yang dihadapi salah satunya adalah kecemasan orangtua siswa pada saat pembelajaran pendidikan jasmani berlangsung. Hasil diskusi dengan orangtua siswa beberapa alasan orangtua cemas kepada anaknya adalah aktivitas anak pada jam pendidikan jasmani dianggap rentan cidera, alasan ini ditemui pada kebanyakan orangtua SD dilevel kelas I dan II, dimana pada jam pendidikan jasmani orangtua siswa selalu memantau dan menunggu anaknya yang sedang beraktivitas dalam pembelajaran pendidikan jasmani. 
Setiap peserta didik memiliki karaktreistik yang berbeda mengacu kepada umur, jenis kelamin, dan jenjang pendidikan (Puspitawati, 2010) Peserta didik sekolah dasar pada umumnya berumur kisaran 7-12 tahun. Anak pada usia ini berada pada emosi yang tidak stabil, mencoba membalas situmulus yang diterima dengan berbagai respon (Mahabbati, 2006). Orangtua tidak sepenuhnya bisa mengawasi anak setiap waktu, sehingga orangtua menempatkan anak pada pendidikan formal yang dapat mendidik dan mendukung perkembangan anak (Umar, 2015). Orangtua diwajibkan harus banyak berkomunikasi dengan guru yang terlibat lansung dengan anak begitu juga sebaliknya.

Orangtua sebagai pengawas yang baik tentu akan menaruh rasa khawatir terhadap apa yang dilakukan anak di luar pengawasannya sehingga menimbulkan kecemasan. Salah satu hal yang membuat orangtua cemas adalah ketika anak disekolah pada jam pelajaran pendidikan jasmani. Seperti yang diketahui pembelajaran ini lebih mengutamakan aktivitas fisik yang mebutuhkan konsentrasi, keberanian, keyakinan dan keterampilan gerak (Fathurrozi et al., 2020). Apabila tidak mendapat pengawasan yang baik dari guru dan konsentrasi yang penuh dari peserta didik, pembelajaran ini tidak lagi membawa kebugaran dan kesehatan namun cedera dan trauma jangka pendek atau panjang pada siswa. Disisi lain seperti isu yang berkembang saat ini mengenai pelecehan yang terjadi pada saat pembelajaran pendidikan jasmani yang dilakukan oleh pihak guru. Secara umum kita ketahui seringnya terjadi interaksi fisik anatara guru dan siswa pada saat pemebelajaran berlansung (The Jakarta Post, 2018) (The Jakarta Post, 2019). Hal seperti ini menjadikan munculnya kecemasan orangtua pada siswa SD pada kelas I dan II yang selalu mengawasi anaknya selama pembelajaran.

Perasaan yang berisikan ketakutan dan berisi keprihatinan merupakan kecemasan mengenai perasaan yang datang tanpa sebab khusus untuk ketakutan tersebut (Chaplin, 2006). Kecemasan ini akan membuat orangtua siswa menjadi kawatir yang berlebihan pada anaknya pada jam pembelajaran pendidikan jasmani. Diartikan bahwa kecemasan dialami secara subjektif dan dikomunikasikan secara interpersonal (Hastuti, 2016). Gejala kecemasan terdapat dalam bentuk dan kompleksitas, namun biasanya cukup mudah dikenali. Cara mudah mendeteksi orangtua siswa yang cemas pada jam pendidikan jasmani salah satunya orangtua siswa selalu memantau aktivitas anaknya diluar pagar 
sekolah sampai jam pendidikan jasmani berakhir. Seseorang yang mengalami kecemasan cenderung untuk selalu merasa khawatir akan keadaan yang buruk yang akan menimpa dirinya atau diri orang lain yang dikenalnya dengan baik (Apriany, 2013). Cemas tidak memandang umur, jender, dan orangtua dalam menjalankan perannya sebagai seorang yang memberi rasa aman kepada keluarga dan anak-anaknya (Indrayani and Santoso, 2012). Namun rasa cemas dapat dikurangi dengan adanya tingkat pemahaman yang lebih baik pada situasi akan kondisi permasalahan yang dihadapai (Resti, 2014).

Secara umum penelitian ini menggali informasi untuk mengetahui tingkat kecemasan orangtua dalam aktivitas belajar pendidikan jasmani yang ditinjau dari ciri-ciri dan gejala kecemasan (Jeffrey S. Nevid, dkk dalam (Fitri Anisa and Ifdil, 2016). Hasil dari penelitian ini dapat memberikan sumbangan pemikiran tidak hanya untuk guru tetapi juga orangtua untuk dapat memberikan perlakuan yang tepat kepada peserta didik sesuai dengan kemampuan, jender dan usia, tetapi juga memberikan pandangan pada orangtua untuk mampu menemukan solusi dalam mengatasi kecemasan yang tidak berdasarkan teori dan fakta dilapangan. Selain itu cara lain yang dapat ditempuh adalah bagaimana peran sekolah dan guru dapat meyakinkan orangtua siswa tentang rasa aman peserta didik dalam mengikuti jam pendidikan jasmani dengan mensosialisasikan kurikulum pendidikan jasmani pada anak tingkat sekolah dasar bahwa pada fase ini anak-anak sangatlah penting untuk bergerak untuk meningkatkan motorik, kognitif dan afektif anak sehingga akan menjadi anak yang aktif serta budaya gerak hidup sehat. Apabila kecemasan orangtua berlangsung tanpa kontrol akan mengakibatkan aktivitas anak dilarang oleh orangtua.

\section{METODE}

Populasi dalam penelitian ini adalah orangtua siswa kelas I sampai dengan kelas VI yang ada di SD Negeri Kota Lintang. Sedangkan yang dijadikan sample dalam penelitian ini adalah orangtua siswa kelas I dan II Sekolah Dasar Negeri Kota Lintang, yang terletak di kota Lintang, Kabupaten Aceh Tamiang Provinsi Aceh dengan jumlah responden sebanyak 58 orang dengan menggunakan purposive sampling yaitu sampel yang memiliki karaktristik tertentu (Nawawi, 2012). 
Penelitian ini menggunakan desain kuantitatif non-eksperimen yang berarti, penelitian ini tidak memberikan perlakuan kepada sampel dan tidak adanya interpensi pada variabel yang terlibat (Maksum, 2012). Metode yang digunakan adalah survei, tekhnik pengambilan data menggunakan angket dan skor yang diperoleh dari angket kemudian dianalisis menggunakan analisis diskriptif kuantitatif yang dituangkan dalam bentuk persentase. Berikut ini adalah tabel kisikisi instrumen angket kecemasan orangtua terhadap pelajaran pendidikan jasmani pada siswa Sekolah Dasar Negeri Kota Lintang.

Tabel. 1 Tabel Kisi- Kisi Instrumen Angket Kecemasan Orangtua Terhadap Pelajaran Pendidikan Jasmani pada Siswa Sekolah Dasar Negeri Kota Lintang.

\begin{tabular}{|c|c|c|c|c|c|}
\hline \multirow[t]{2}{*}{ Variabel } & \multirow[t]{2}{*}{ Faktor } & \multirow[t]{2}{*}{ Indikator } & \multicolumn{2}{|c|}{ Butir Soal } & \multirow[t]{2}{*}{ Jumlah } \\
\hline & & & Positif & Negatif & \\
\hline \multirow{4}{*}{$\begin{array}{l}\text { Kecemasan } \\
\text { orangtua } \\
\text { terhadap } \\
\text { pembelajaran } \\
\text { pendidikan } \\
\text { jasmani pada } \\
\text { siswa SD Negeri } \\
\text { Kota Lintang }\end{array}$} & $\begin{array}{c}\text { Faktor } \\
\text { Fisiologis }\end{array}$ & Gelisah & 4,5 & 13 & 3 \\
\hline & $\begin{array}{c}\text { Faktor } \\
\text { Psikilogis }\end{array}$ & $\begin{array}{l}\text { Khawatir } \\
\text { tentang } \\
\text { sesuatu }\end{array}$ & 12,15 & 17,18 & 4 \\
\hline & & $\begin{array}{l}\text { Perasaan } \\
\text { aman dan } \\
\text { senang }\end{array}$ & 19 & $1,6,9$ & 4 \\
\hline & & Ketakutan & $8,10,11$ & 14 & 4 \\
\hline
\end{tabular}

Penelitian ini menggunakan instrumen angket. Kajian teori angket kecemasan tersusun dalam dua aspek, yaitu aspek psikologis dan aspek fisiologis yang kemudian setiap aspek dijabarkan kedalam indikator (Nawawi, 2012). Kemudian indikator dituangkan dalam bentuk butir aitem. Butir angket dapat dinyatakan dalam dua bentuk, yaitu pernyataan bersifat positif dan pernyataan yang bersifat negatif. Pernyataan positif pernyataan yang mendukung aspek kecemasan. sedangkan pernyataan negatif pernyataan yang tidak mendukung aspek kecemasan.

Sedangkan pengisian angket dengan metode pengisian skala likert dengan pilihan angka 4, 3, 2, dan 1 pada tiap butirnya. Berikut empat pilihan angket dengan menggunakan skala likert dapat dilihat pada Tabel 2 di bawah ini. 
Tabel 2. Kriteria Angket

\begin{tabular}{cc}
\hline Angka & Kriteria \\
\hline 4 & Sangat Setuju (SS) \\
\hline 3 & Setuju (S) \\
\hline 2 & Tidak Setuju (TS) \\
\hline 1 & Sangat Tidak Setuju (STS) \\
\hline
\end{tabular}

Sumber: (Arikunto, 2006)

Instrumen ditentukan oleh suatu kesahihan (validitas) serta keandalan (reliabilitas). Rumus yang dipakai untuk validitas instrumen dengan Pearson Product Moment (Arikunto, 2006) dan untuk uji realibitas menggunakan Alpha Cronbach (Arikunto, 2006). Setelah data terkumpul secara keseluruhan dari hasil tes, tahap selanjutnya adalah tahap analisis data, data diolah dengan menggunakan rumus untuk menghitung frekuensi relatif (persentase).

\section{HASIL DAN PEMBAHASAN}

Pada bagian ini membahas hasil data penelitian yang diperoleh setelah dilakukan sebaran kuesioner dan uji statistik meliputi data indikator 1. Faktor Fisiologis dengan Sub Indikator Gelisa, 2. Indikator Psikologis dengan Sub Indikator. khawatir tentang sesuatu, perasaan aman dan senang, ketakutan seperti yang tertera pada tabel 3 .

Tabel 3. Persentase dan Rekapitulasi Data Setiap Indikator/Sub Indikator

\begin{tabular}{llcccc}
\hline No & Indikator/ Sub Indikator & \multicolumn{3}{c}{ Skor } & \multirow{2}{*}{ Kategori } \\
\cline { 3 - 4 } & & Mentah & Seharusnya & Persentase & \\
\hline $\mathbf{1}$ & Faktor Fisiologis : & 345 & 464 & $74,3 \%$ & Tinggi \\
& $\begin{array}{l}\text { - Gelisa } \\
\text { 2 }\end{array}$ & Faktor Psikologis : & & & \\
& - Khawatir tentang sesuatu & 331 & 464 & $71,3 \%$ & Tinggi \\
& - Perasaan aman dan senang & 280 & 464 & $60,3 \%$ & Tinggi \\
& - Ketakutan & 346 & 464 & $74,5 \%$ & Tinggi \\
\hline$\quad$ Jumlah & 1302 & 1856 & $70,1 \%$ & Tinggi \\
\hline
\end{tabular}

Dari tabel data diatas menunjukkan bahwa jumlah persentase tingkat kecemasan orangtua terhadap pelajaran pendidikan jasmani pada tingkat kelas I dan II pada indikator fisiologis dan psikologis yakni sebesar $70,1 \%$. Berada pada rentang skor 50\%-70\%. Persentase ini menunjukan tingkat kecemasan orangtua 
terhadap pelajaran pendidikan jasmani berada dalam kategori tinggi yaitu pada indikator faktor fisiologis sub indikator gelisah sebesar 74,3\%. Tingkat kecemasan berdasarkan faktor psikologis pada sub indikator khawatir tentang sesuatu sebesar 71,3\%, pada sub indikator perasaan aman dan senang sebesar $60,3 \%$, dan pada sub indikator ketakutan sebesar 74,5\%.

Berdasarkan hasil data penelitian dapat diperoleh informasi mengapa kecemasan orangtua siswa muncul pada pembelajaran pendidikan jasmani. Pada sub indikator gelisah muncul dalam bentuk cemas apabila anak tidak bisa menguasai gerakan yang rentan dengan cidera, cemas apabila anak mempelajari pendidikan jasmani dan tidak kosentrasi pada pelajaran lainnya. Pada sub indikator khawatir tentang sesuatu orangtua siswa khawatir apabila anak melakukan aktivitas dengan antusias tinggi sehingga menyebabkan kelelahan. Pada sub indikator perasaan aman dan senang orangtua siswa antusias melihat anaknya apabila guru memahami kondisi anak dan anak mampu mengikuti gerakan yang diajarkan. Pada sub indikator ketakutan orangtua siswa cemas bila guru tidak menggunakan media pembelajaran yang sesuai dan rasa takut muncul ketika pembelajaran penjas dilaksanakan pada saat cuaca mulai panas.

Faktor-faktor ini yang menyebabkan orangtua peserta didik menganggap pelajaran pendidikan jasmani merupakan pelajaran ekstrakulikuler yang kurang dibutuhkan dan penting sehingga menimbulkan khawatir dan takut ketika peserta didik saat melalukan peraktikum pelajaran pendidikan jasmani. Orangtua merasa bahwa telah melakukan kesalahan apabila anaknya mengalami cedera, orangtua juga begitu cemas dan takut bila anak yang mengikuti kegiatan praktikum yang dianggap berbahaya. Namu disisilain orangtua merasa aman dan senang pada pandangan bahwa mengikuti pelajaran pendidikan jasmani anak akan dibentuk karakter yang berani dan disiplin.

Kecemasan orangtua baik dari gejala fisiologi dan psikologi tidak hanya dipengaruhi dari kegitan belajar mengajar. Penelitian lain yang relevan dengan penelitian ini, seperti kecemasan orangtua pada saat anak dirawat di rumah sakit (Apriany, 2013), faktor kekerasan seksual yang terjadi di lingkungan bermain (cinantya, 2014). Ini merupakan salah satu indikator mengapa orangtua siswa cemas terhadap anaknya, karena dalam penelitian ini hanya mengkaji kecemasan pada pembelajaran pendidikan jasmani, relevan dengan penelitian lain yang 
dikutip faktor kekerasan seksual serta maraknya kasus pedofilia pada anak juga menjadi salah satu kecemasan orangtua terhadap anak.

\section{SIMPULAN}

Hasil penelitian serta pembahasan dapat disimpulkan bahwa tingkat kecemasan orangtua terhadap pelajaran pendidikan jasmani pada siswa SDN Kota Lintang tergolong tinggi. Kecemasan cukup tinggi ini terdapat pada siswa kelas I dan II. Untuk itu, perlunya ditingkatkan komunikasi dan sosialisasi yang berkelanjutan dari pihak sekolah yaitu guru dan perangkat sekolah dengan orangtua siswa. Orangtua juga perlu diberikan bimbingan atau pandangan tentang pembelajaran pendidikan jasmani baik dari tujuan dan manfaat mengikuti pembelajaran ini karena berperan dalam proses tumbuh kembang, kebenaran gerakan juga meberikan penjelasan bahawa pembelajaran pendidikan jasmani bukan seperti apa yang orangtua pikirkan yaitu hanya akan membuat anak lelah, cedera, dan stigma negatif lainnya karena pada tingkat sekolah dasar adalah bagaimana kita membangun karakter anak untuk memiliki kebiasaan gerak dengan berolahraga dimana salah satunya anak bisa dapatkan adalah pada jam pembelajaran pendidikan jasmani di sekolah.

\section{DAFTAR RUJUKAN}

Apriany, D., 2013. Hubungan Antara Hospitalisasi Anak Dengan Tingkat Kecemasan Orang Tua. Jurnal Keperawatan Soedirman 8(2). Https://Doi.Org/10.20884/1.Jks.2013.8.2.477

Arikunto, S., 2006. Prosedur Penelitian Suatu Pendekatan Praktik. Jakarta. Pt. Rineka Cipta, Jakarta.

Chaplin, J., 2006. Kamus Lengkap Psikologi. ( Terjemahan: Kartini Kartono). Pt. Raja Grafindo Jaya, Jakarta.

Cinantya, Adinda Sekar, 2014. Hubungan Terpaan Berita Kekerasan Seksual Pada Anak Di Televisi Dan Tingkat Kecemasan Orang Tua Dengan Intensitas Komunikasi Orang Tua Dan Anak. Interaksi Online, 3(1).

Depdiknas, 2006. Kurikulum Tingkat Satuan Pendidikan. Dekdikna, Jakarta.

Fathurrozi, F., Triansyah, A., Hidasari, F.P., 2020. Tingkat Kecemasan Peserta Didik Pada Pembelajaran Kayang Di Smp Islam Bawari Pontianak. Jurnal Pendidikan Dan Pembelajaran Khatulistiwa 9(1). 
Fitri Anisa, D., Ifdil, 2016. Konsep Kecemasan( Anxiety) Pada Lanjut Usia. Konselor 5(2), 93-99.

Hastuti, R.P., 2016. Analisis Faktor Yang Berhubungan Dengan Tingkat Kecemasan Orang Tua Anak Thalasemia Di Rsud Ahmad Yani Metro. Jurnal Kesehatan Metro Sai Wawai 8(2), 49-54. Https://Doi.Org/10.26630/Jkm.V8i2.179

Indrayani, A., Santoso, A., 2012. Hubungan Pendidikan Kesehatan Dengan Kecemasan Orang Tua Pada Anak Hospitalisasi. Jurnal Keperawatan Diponegoro 1(1), 163-168.

Mahabbati, A., 2006. Identifikasi Anak Dengan Gangguan Emosi Dan Perilaku. Jurnal Pendidikan Nasional 2, 1.

Maksum, A., 2012. Metodologi Penelitian Dalam Olahraga. Unesa University Press, Surabaya.

Nawawi, H., 2012. Metode Peneltian Bidang Sosial. Gajah Mada University Press, Yogtakarta.

Puspitawati, H., 2010. Pengaruh Karakteristik Sosial Ekonomi Keluarga Terhadap Pola Asuh Belajar Siswa Sekolah Dasar Dan Menengah Pertama. Jurnal Ilmu Keluarga \& Konsumen 3(1), 46-55. Https://Doi.Org/10.24156/Jikk.2010.3.1.46

Resti, I.B., 2014. Teknik Relaksasi Otot Progresif Untuk Mengurangi Stres Pada Penderita Asma | Resti | Jurnal Ilmiah Psikologi Terapan. Jurnal Ilmiah Psikologi Terapan 2(1), 01-20.

Setyawan, T., 2018. Pengembangan Buku Ajar Pendidikan Jasmani Dan Olahraga Melalui Pendekatan Saintifik Kelas Iv Sdn Nguter 02 Lumajang. Jp. Jok (Jurnal Pendidikan Jasmani, Olahraga Dan Kesehatan) 1(2), 24-46.

The Jakarta Post, 28 Juli, 2019. Pe Teacher Arrested For Allegedly Molesting Student. Jakarta 1-3.

The Jakarta Post, 13 Januari, 2018. Teacher Suspected Of Molesting Students In East Jakarta. Jakarta.

Umar, M., 2015. Peranan Orang Tua Dalam Peningkatan Prestasi Belajar Anak. Jurnal Edukasi: Jurnal Bimbingan Konseling 1(1), 20-28.

Widiyatmoko, F. Ari, Hudah, M., 2017. Evaluasi Implementasi Pendidikan Nilai Dalam Pembelajaran Penjas. Jurnal Ilmiah Penjas (Penelitian, Pendidikan dan Pengajaran) 3(2). 